\title{
Novel RP-HPLC Method Development and Validation of Meloxicam Suppository
}

\author{
Sufiyan Ahmad" ${ }^{1 \star}$, Sharma Deepika1, Patil Amol', Warude Kapil', Md. Rageeb Md.Usman² \\ 1'Department of Quality Assurance, Gangamai College of Pharmacy, Nagaon, Dist-Dhule (Maharashtra), INDIA. \\ ${ }^{2}$ Department of Pharmacognosy, Smt. Sharadchandrika Suresh Patil College of Pharmacy, Chopda, Maharashtra, INDIA.
}

\begin{abstract}
Objective: A simple reversed-phase high-performance liquid chromatographic (RP-HPLC) method has been developed and validated for simultaneous determination of Meloxicam drug (MLX) in pharmaceutical mixture. Methods: Effective chromatographic separation achieved using a phenomenex luna $\mathrm{C}_{18}(4.6 \mathrm{~mm}, 250 \mathrm{~mm}, 5 \mu \mathrm{m})$ column with isocratic elution by the mobile phase composed of $0.02 \mathrm{M}$ Potassium dihydrogen orthophosphate, $\mathrm{pH}$ adjusted to 4 with orthophosphoric acid (filtered): acetonitrile (50:50) respectively. The flow rate is $1.0 \mathrm{ml} / \mathrm{min}$ on detecting wavelength $220 \mathrm{~nm}$. Results: The proposed HPLC method was statistically validated with respect to linearity, ranges, precision, accuracy, selectivity, LOD, LOQ and robustness. The retention time (RT) of Meloxicam was found to be $6.0 \mathrm{~min}$. respectively. All parameters were found to be within the acceptance limit. The calibration curve was linear in ranges of 3-6, 6-9, and 15-18 mg/ $\mathrm{ml}$ for Meloxicam. The $\mathrm{R}^{2}$ of Meloxicam was found to be 0.996 respectively. Conclusion: A novel simple, simple, sensitive, precise, rapid, accurate and economical and reliable RP-HPLC method was developed and validated for the Meloxicam suppository.

Key words: Meloxicam, RP HPLC, Method Development, Validation, Suppository, Novel.
\end{abstract}

\section{INTRODUCTION}

Meloxicam is chemically designated as 4-hydroxy-2-methyl-N-(5-methyl-2thiazolyl)-2H-1,2-benzothiazine-3-carboxamide-1,1-dioxide [Figure 1] The molecular weight is $351.4 \mathrm{gm} /$ moles. Its empirical formula is $\mathrm{C}_{14} \mathrm{H}_{13} \mathrm{~N}_{3} \mathrm{O}_{4} \mathrm{~S}_{2}$. Meloxicam is highly soluble in strong acids and bases. It has $\mathrm{pKa}$ values of 1.1 and $4.2 .^{1-3}$

Meloxicam is an NSAID of the oxicam class that acts by inhibiting the prostaglandin synthesis and inducible COX-2, thereby exerting anti-inflammatory, analgesic and antipyretic effects. The molecule is highly plasma protein bound when circulating in the body (95-99\%). It has a long plasma half-life, enabling less frequent dosage schemes. ${ }^{47}$

The detailed literature survey divulges bio analytical method for the analysis of Meloxicam individually and in various combinations in biological matrices. ${ }^{8}$ and few RP- HPLC methods for the determination of assay of Meloxicam in bulk and in tablet and capsule dosage form . ${ }^{9-10}$

Method validation is an important issue in drug analysis according to conventional regulations such as FDA, EMEA and $\mathrm{ICH}$. The process confirms that the analytical procedure employed for the analysis is suitable for its intended use and to show reliability of the results produced by any method. Therefore method validation is essential in drug analysis.

However, to best of our knowledge, no reported RP-HPLC method have ever been reported in literature for the development and validation of Meloxicam suppository. The aim of present study, the authors report a simple, sensitive, sensitive, precise, rapid, accurate and economical and reliable RP-HPLC method was developed and validated for the Meloxicam suppository.
Submission Date: 09-02-2017; Revision Date: 14-03-2017; Accepted Date: 13-07-2017

DOI: 10.5530/ijper.51.4.95 Correspondence: Dr. Sufiyan Ahmad, Department of Quality Assurance, Gangamai College of Pharmacy, Nagaon, Dist-Dhule (Maharashtra ), INDIA

Mobile. 09970865798

E-mail: sufimpharm@ rediffmail.com

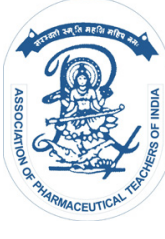

www.ijper.org 


\section{MATERIAL AND METHOD}

\section{Chemicals and reagents}

Working standards of pharmaceutical grade Meloxicam were obtained as generous gifts sample from Swati Pantose, Alkan bioscience Pvt. Ltd. Mumabi. They were used without further purification. Fixed dose tablet was purchased from local market. All the chemicals were of HPLC grade, purchased from Thomas Baker, Loba chemical laboratory reagent and fine chemicals, S D Fine chem. limited, water used was double distilled and filtered through $0.45 \mu \mathrm{m}$ filter paper.

\section{Instrumentation}

The HPLC system consisted of Shimadzu (LC-20AD) Gradient System UV detector. Spinchrom software used. The chromatographic separations were carried out on a reverse phase phenomenex Luna $\mathrm{C}_{18}$ column $(4.6 \times 250 \mathrm{~mm}$ i. d., particle size $5 \mu \mathrm{m})$.

\section{Chromatographic Conditions}

The HPLC method was optimized with a view to develop a reversed-phase HPLC method for Meloxicam in pharmaceutical dosage form. A well-defined symmetrical peak was obtained upon measuring the response of eluent under the optimized conditions after thorough experimental trials that can be summarized.

Columns used for the study was Phenomenex Luna C18 (250 mm X $4.6 \mathrm{~mm}, 5 \mu$ ) column. It produced symmetrical peaks with high resolution. The UV detector response of Meloxicam was studied and the best wavelength was found to be $220 \mathrm{~nm}$ showing highest sensitivity.

Development studies revealed that a mobile phase containing $0.02 \mathrm{M}$ Potassium dihydrogen orthophosphate ( $\mathrm{pH}$ adjusted to 4 with Orthophosphoric acid) and Acetonitrile in the ratio of 50:50at the flow rate of $1 \mathrm{ml} / \mathrm{min}$ was suitable for simultaneous estimation of Meloxicam. Objectives in chromatographic method development were to achieve a peak tailing factor not more than 2. Under the optimized conditions Meloxicam gave sharp peaks with minimum tailing and good resolution.

\section{Preparation of standard stock and sample solution Preparation of standard stock solution}

$15 \mathrm{mg}$ of Meloxicam were weighed accurately in a $100 \mathrm{ml}$ volumetric flask respectively. $80 \mathrm{ml}$ of the mobile phase was added, sonicated to dissolve and diluted to volume with the mobile phase. Further, $1 \mathrm{ml}$ of this solution was diluted to $10 \mathrm{ml}$, respectively, with the mobile phase. The resultant mixture was subjected to HPLC analysis in developed chromatographic conditions [Figure 2].

\section{RESULTS AND DISCUSSION}

\section{Method development and optimization of chromatographic conditions}

Experiments previously suggest use of $\mathrm{C}_{18}$ stationary phase of $(250 \mathrm{~mm}, 4.5 \mathrm{~mm}$ i. d., and particle size $5 \mu \mathrm{m})$ hence for the study a reverse phase $\mathrm{C}_{18}$ column made by core shell technology was utilized. Parameter such as mobile phase composition of buffer was exhaustively studied so as to achieve a reasonable degree of separation of analyte. Several binary or ternary eluants were tested using different proportions of solvent, such as acetonitrile, methanol, water and buffer at different $\mathrm{pH}$ conditions. Initially isocratic mode of separation was experimented and was found insufficient to resolve the mixture with good peak characters but after many trial methods developed in isocratic system. Method selected so as to achieve separation of analytes with good peak characters. The mean retention time of analyte was 6 min. Peak identification was done by injecting individual analyte in developed chromatographic conditions.

\section{Method Validation}

\section{Accuracy}

Standard drug solution was added to the pre-analyzed suppositories sample solution at the three different concentration levels $(80 \%, 100 \%$, and $120 \%$ ) within the range of linearity of the drug. Results are shown in Table 1.

Acceptance criteria: Accuracy should be between 98\% $102 \%$ and $\%$ RSD should not be more than 2.0.

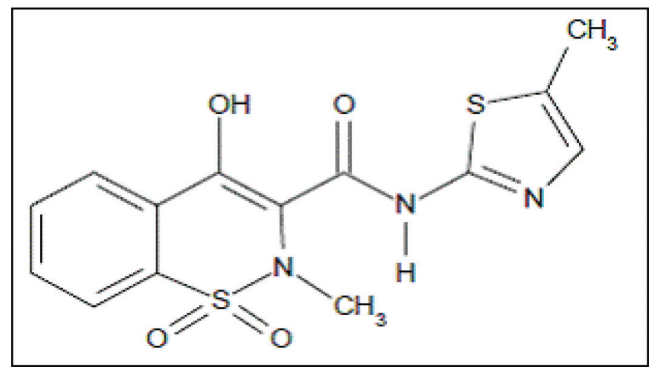

Figure 1: Structure of Meloxicam

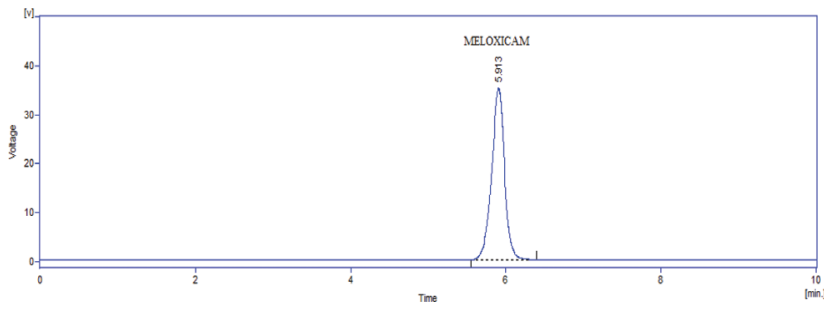

Figure 2: Chromatogram of Meloxicam $(150 \mu \mathrm{g} / \mathrm{ml})$ in $0.02 \mathrm{M}$ potassium dihydrogen orthophosphate ( $\mathrm{pH}$ adjusted to 4 with orthophosphoric acid) and acetonitrile (50:50) at $220 \mathrm{~nm}$ 


\section{Table 1: Data for accuracy of Meloxicam}

\begin{tabular}{|c|c|c|c|c|}
\hline $\begin{array}{c}\text { Level no/ spike } \\
\text { level in \% }\end{array}$ & \% Recovery & Mean & SD & $\%$ RSD \\
\hline \multirow{3}{*}{$\begin{array}{c}\text { Level - } 1 \\
(80 \%)\end{array}$} & 101.32 & \multirow{3}{*}{100.29} & \multirow{3}{*}{1.106} & \multirow{3}{*}{1.10} \\
\hline & 99.12 & & & \\
\hline & 100.42 & & & \\
\hline \multirow{3}{*}{$\begin{array}{c}\text { Level - } 2 \\
(100 \%)\end{array}$} & 99.64 & \multirow{3}{*}{99.93} & \multirow{3}{*}{0.376} & \multirow{3}{*}{0.38} \\
\hline & 100.36 & & & \\
\hline & 99.81 & & & \\
\hline \multirow{3}{*}{$\begin{array}{c}\text { Level - } 3 \\
(120 \%)\end{array}$} & 99.55 & \multirow{3}{*}{99.16} & \multirow{3}{*}{0.418} & \multirow{3}{*}{0.42} \\
\hline & 99.23 & & & \\
\hline & 98.72 & & & \\
\hline \multicolumn{2}{|c|}{ Overall mean $\%$ recovery } & \multicolumn{3}{|c|}{99.79} \\
\hline \multicolumn{2}{|c|}{ Overall SD } & \multicolumn{3}{|c|}{0.633} \\
\hline \multicolumn{2}{|c|}{ Overall \% RSD } & \multicolumn{3}{|c|}{0.633} \\
\hline
\end{tabular}

*mean and \% relative standard deviation of six replicates

\begin{tabular}{|c|c|}
\hline \begin{tabular}{|c|} 
Table 2: Data for system precision of Meloxicam \\
\hline Sample No.
\end{tabular} \\
\hline 1 & Peak area of Meloxicam \\
\hline 2 & 202.077 \\
\hline 3 & 202.591 \\
\hline 4 & 199.781 \\
\hline 5 & 203.157 \\
\hline 6 & 201.230 \\
\hline Mean & 203.949 \\
\hline SD & 202.130 \\
\hline$\%$ RSD & 1.476 \\
\hline
\end{tabular}

\begin{tabular}{|c|c|}
\hline \multicolumn{2}{|c|}{ Table 3: Linearity data for Meloxicam } \\
\hline Concentration of Meloxicam in $\boldsymbol{\mu g} / \mathbf{m l}$ & Peak areas \\
\hline 03 & 49.051 \\
\hline 06 & 77.331 \\
\hline 09 & 120.824 \\
\hline 12 & 161.495 \\
\hline 15 & 202.332 \\
\hline 18 & 231.637 \\
\hline Slope & 189.7 \\
\hline Intercept & 7.598 \\
\hline $\mathrm{R}^{2}$ & 0.996 \\
\hline
\end{tabular}

\section{Precision}

System precision: A six replicates injection of the standard solution was injected into the HPLC system. The mean, $\mathrm{SD}$ and $\%$ RSD for peak areas of Meloxicam were calculated. Results are shown in Table 2.

Acceptance criteria: \% RSD should not be more than 2.0.

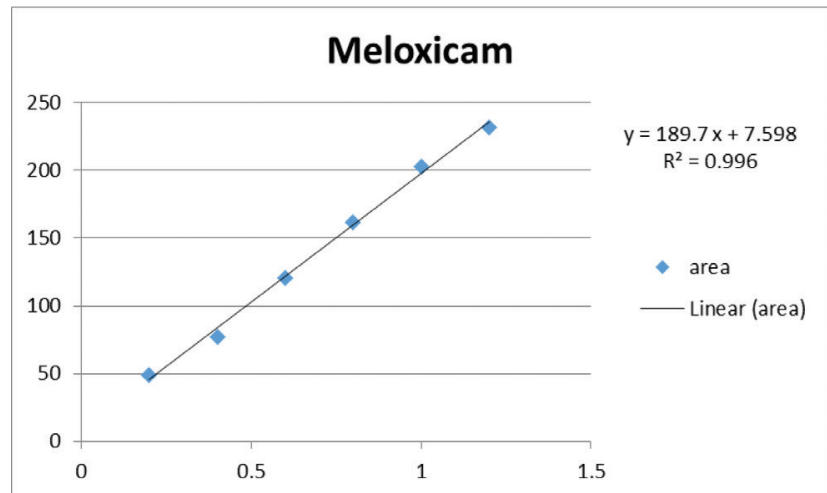

Figure 3: Calibration curve of Meloxicam

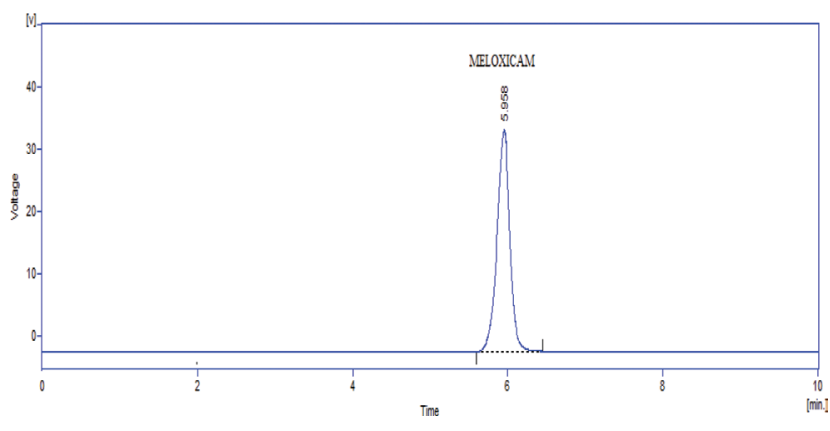

Figure 4.1: Chromatogram of standard solution in plus flow

\section{Specificity}

Specificity of the method was evaluated by injecting the blank (mobile phase), standard and sample solution prepared as per the proposed method and injected into the HPLC system to check interference if any at the retention time of Meloxicam.

Acceptance criteria: No peaks shall be eluted at the retention time Meloxicam in blank.

\section{Linearity}

Linearity of Meloxicam was performed using a standard solution in the range of $3-18 \mu \mathrm{g} / \mathrm{ml}$ respectively. Results are shown in Table 3 and Figure 3.

Acceptance criteria: Correlation coefficient $\left(\mathrm{R}^{2}\right)$ should be not less than 0.99 .

Range: Range is inferred from the data of linearity, recovery and precision experiments.

Acceptance criteria: The range of the method based on the results from the linearity, accuracy and precision studies.

\section{Robustness}

Robustness of the method was evaluated by changing the flow rate by $\pm 10 \%$ and by changing the organic content by $\pm 2 \%$ absolute. Results are shown in Table 4 and Figure 4.1-4.4

Acceptance criteria: \% RSD should be not more than 2.0. ${ }^{11-18}$ 
Table 4: Robustness data for Meloxicam

\begin{tabular}{|c|c|c|c|c|c|c|c|}
\multirow{2}{*}{ Sr. No. } & Parameters & \multicolumn{3}{|c|}{ \% Assay } & Over all & Over all & \multirow{2}{*}{ Over all \%RSD } \\
\cline { 3 - 7 } & & $\mathbf{1}$ & $\mathbf{2}$ & $\mathbf{3}$ & $\mathbf{\text { SD }}$ & & \\
\hline I & Plus flow $(1.1 \mathrm{ml} / \mathrm{min})$ & 98.59 & 98.81 & 99.10 & 98.83 & 0.255 & 0.26 \\
\hline II & Minus flow $(0.9 \mathrm{ml} / \mathrm{min})$ & 100.79 & 101.067 & 101.05 & 101.29 & 0.517 & 0.05 \\
\hline III & Plus Organic (+2\%) & 99.45 & 99.42 & 99.54 & 99.47 & 0.0624 & 0.06 \\
\hline IV & Minus Organic (-2\%) & 101.34 & 101.61 & 101.056 & 101.33 & 0.277 & 0.027 \\
\hline
\end{tabular}

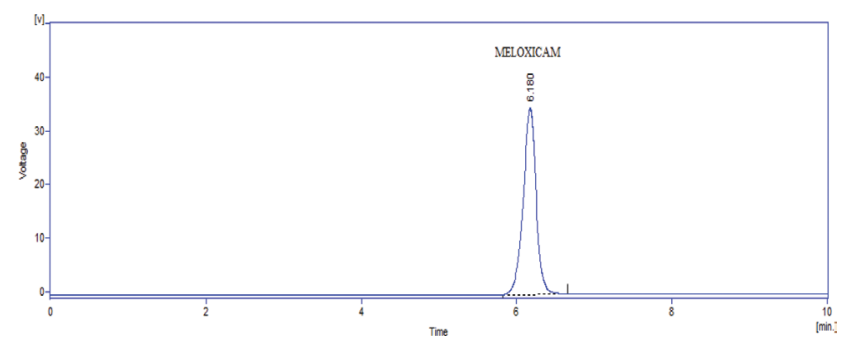

Figure 4.2: Chromatogram of standard solution in minus flow

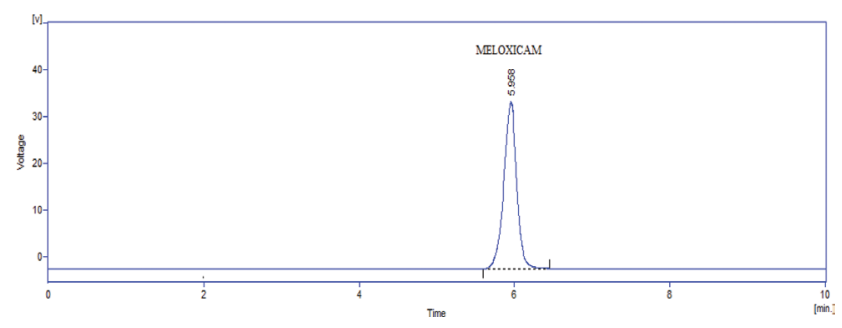

Figure 4.3: Chromatogram of standard solution in plus organic

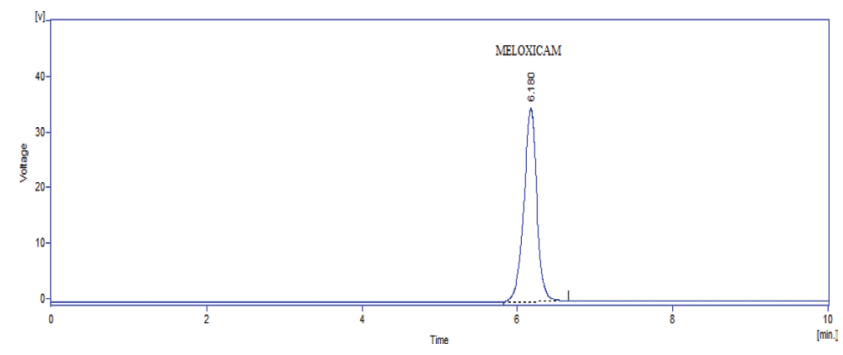

Figure 4.4: Chromatogram of standard solution in minus organic

\section{CONCLUSION}

Attempts were made to develop RP-HPLC method for simultaneous estimation of Meloxicam for the RP - HPLC method. Effective chromatographic separation achieved using a primesil C18 $(4.6 \mathrm{~mm}, 250 \mathrm{~mm}, 5 \mu \mathrm{m})$ column with isocratic elution by the mobile phase composed of $0.02 \mathrm{M}$ potassium dihydrogen orthophosphate ( $\mathrm{pH}$ adjusted to 4 with orthophosphoric acid: acetonitrile (50:50) respectively. The flow rate is $1.0 \mathrm{ml} / \mathrm{min}$ on detecting wavelength $220 \mathrm{~nm}$. The proposed HPLC method was statistically validated with respect to linearity, ranges, precision, accuracy, selectivity, LOD, LOQ and robustness. The retention times (RT) of Meloxicam were found to be $6.0 \mathrm{~min}$. respectively. All parameters were found to be within the acceptance limit. The calibration curve was linear in ranges of 3-6, 6-9, and $15-18 \mathrm{mg} / \mathrm{ml}$ for Meloxicam. The $\mathrm{R}^{2}$ of Meloxicam was found to be 0.996 respectively.

Linearity study of Meloxicam was done successfully. The calibration curve yielded correlation coefficient $\left(\mathrm{r}^{2}\right)$ 0.996. Precision both intraday, inter-day study done. The results of the Precision study with in the acceptance limit. In system suitability study Retention time, Area, Theoretical plate number, Tailing factor etc parameters study done successfully.

In robustness study change in selected parameter like Flow rate, Mobile phase composition, Wave length. The results of robustness study shows less variability in retention time and tailing factor.

\section{ACKNOWLEDGMENT}

The authors are grateful thanks to the Pharmaceutical Company for providing gift sample of Meloxicam Suppository. Authors are also thankful to Management and Principal of Gangamai College of Pharmacy, Nagaon, Dhule for providing timely support for the research work.

\section{CONFLICT OF INTEREST}

Authors have no conflicts of interest to declare.

\section{ABBREVIATION USED}

HPLC: High performance liquid chromatography; UV: ultraviolet; ICH: International Conference on Harmonization; LOQ: Limit of quantitation; LOD: Limit of detection; RSD: Relative standard deviation; MLX : Meloxicam; RT: Retention time; NSAID: Nonsteroidal anti-inflammatory drugs; COX-2: Cyclooxygenase-2; 
FDA: Food and Drug Administration; SD: Standard deviation.

\section{REFERENCES}

1. Beckett A H, Stenlake J B, Practical Pharmaceutical Chemistry, 4th edition, Part II, CBS Publications and Distributors, New Delhi; 1997, p. 275-300.

2. Dasandi B, Saroj H, Bhat KM. LC determination and pharmacokinetics of meloxicam. Journal of pharmaceutical and biomedical analysis. 2002 Jun 1;28(5):999-1004. https://doi.org/10.1016/S0731-7085(02)00064-X.

3. Nemutlu E, Sayin F, Basci NE, Kir S. A validated HPLC method for the determination of meloxicam in pharmaceutical preparations. HACETTEPE UNIVERSITY JOURNAL OF FACULTY OF PHARMACY. 2007;27(2):107.

4. Bandarkar FS, Vavia PR. A stability indicating HPLC method for the determination of meloxicam in bulk and commercial formulations. Tropical Journal of Pharmaceutical Research. 2009;8(3). https://doi.org/10.4314/tjpr. v8i3.44543.

5. Ferenczi-Fodor K, Renger B, Végh Z. The frustrated reviewer-recurrent failures in manuscripts describing validation of quantitative TLC/HPTLC procedures for analysis of pharmaceuticals. JPC-Journal of Planar Chromatography-Modern TLC. 2010;23(3):173-9. https://doi.org/10.1556/ JPC.23.2010.3.1.

6. Gary C D, Analytical chemistry, 5th edition, John Wiely \& sons, Inc., 2001; p. 1 - 3.

7. Heftmann E, editor. Chromatography: Fundamentals and applications of chromatography and related differential migration methods-Part B: Applications. Elsevier; 2004 Apr 16.
8. Kasture A V, Wadodkar S G, Mahadik K R, and More H N, Textbook of Pharmaceutical Analysis - II, 11th edition, Published By Nirali Prakashan, 1996; p. 156-165.

9. Katz E. Quantitative Anallysis Using Chromatographic Techniques. John Wiley \& Sons; 2009.

10. Arayne MS, Sultana NA, Siddiqui FA. A new RP-HPLC method for analysis of meloxicam in tablets. Pak J Pharm Sci. 2005;18(1):58-62. PMid:16431386.

11. Mendum J, Denny R C, Thomas M N, Vogel's Text book of Quantitative Analysis, 6th edition, Pearson education Ltd., 2004: p. 268.

12. Sinha PK, Jeswani RM, Topagi KS, Damle MC. A validated RP-HPLC method for determination of Meloxicam in the Presence of its Impurities. International J. of Pharm Tech Research. 2009(1):1051-60.

13. Renger B, Végh Z, Ferenczi-Fodor K. Validation of thin layer and high performance thin layer chromatographic methods. Journal of Chromatography A. 2011;1218(19):2712-21. https://doi.org/10.1016/j.chroma.2011.01.059; PMid:21329932.

14. Scott P W, Liquid Chromatography Column Theory, John Willey and Sons, Chi Chester, 2001; p. 1-13.

15. Sethi P D, HPTLC: Quantitative Analysis of Pharmaceutical formulation, 1stedition, CBS Publications, New Delhi, 1996; p.162-165.

16. Sethi P D, Introduction - High Performance Liquid Chromatography, 1st edition, CBS Publishers, New Delhi, 2001; p.1-28.PMid:11232735.

17. Sharma B K, Instrumental Method of chemical Analysis, 21stedition, Goel publishing house, 2002; p. 9-16.

18. Sharma B K, Instrumental Method of Chemical Analysis, 21th edition, Goel Publishing Housing, 2002; p. 3. PMCid:PMC154108.

\section{PICTORIAL ABSTRACT}<smiles>Cc1cnc(NC(=O)C2=C(O)c3ccccc3S(=O)(=O)N2C)s1</smiles>

\section{About Authors}

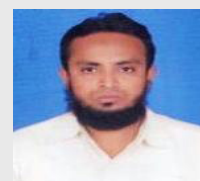

Sufiyan Ahmad: Dr. Sufiyan Ahmad Raees Ahmad had completed B. Pharm from A. R. A. College of Pharmacy, Dhule (North Maharashtra University), M. Pharm from Vinayaka Missions College of Pharmacy, Salem (T.N.) and Doctorate in Pharmacy from JJT University (Rajasthan). He is presently working as associate professor and head of department in Pharmacognosy at GangamaiCollege of Pharmacy, Nagaon, Dist. Dhule. He is life member of various Professional organizations such as Association of Pharmaceutical Teachers of India (APTI), In Pharm Association A Young Pharmacists group, Association of Pharmacy Professionals (APP) and Society of Pharmaceutical Education and Research (SPER). He has guided 11 PG students. UGC has sanctioned one minor research project to him. He has participated in various National and International conferences. He has extensive work in the field of Pharmaceutical Sciences and has contributed number of research and review article publications in high reputed international and national journals.

Sharma Deepika: Miss. Sharma Deepika, PG Student, Department of Quality Assurance, Gangamai College of Pharmacy, North Maharashtra University, Jalgaon (M.S.) India

Patil Amol: Mr. Patil Amol, PG Student, Department of Quality Assurance, Gangamai College of Pharmacy, North Maharashtra University, Jalgaon (M.S.) India.

Warude Kapil: Mr. Warude Kapil, PG Student, Department of Quality Assurance, Gangamai College of Pharmacy, North Maharashtra University, Jalgaon (M.S.) India. 


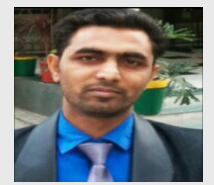

Md. Rageeb Md. Usman: Md. Rageeb Md. Usman, Completed B. Pharm., M. Pharm. (Pharmacognosy) from North Maharashtra University, Jalgaon; Asst. Prof, in Pharmacognosy Dept, at Smt. Sharadchandrika Suresh Patil College of Pharmacy, Chopda. He is highly Professional academician and Researcher in Pharmacy field. Md. Rageeb over 9 Year Experience in Teaching, Research and authorship of books. He has to his Name more than 15 books, 1 chapter in book, 60 Research/ Review publications and 190 Presentation/Participation of National/International Conferences. Md. Rageeb Life Member: Asscn. of Pharmaceutical Teachers of India, Soc. of Pharmaceutical Education \& Research (Joint Secretary, Central Br), Asscn. of Pharmacy Professionals (President, Maharashtra State Br.), Indian Hospital Pharmacists Asscn, Indian Pharmacy Graduates Asscn, Indian Pharmacists Asscn. (President, Jalgaon Br.), Research Scholar Hub (Maharashtra State $\mathrm{Br}$.), Soc. of Researchers \& Healthcare Professionals (President, Maharashtra State Br), Indian Pharmaceutical Asscn; Member: Indian Soc of Pharmacognosy, Asscn of Biotechnology \& Pharmacy, International Natural Hygiene Soc; Assoc Editor/Editor of several professional journals and magazines. He Conferred Fellowship Award 2013 (twice), 2014, 2015 (twice), Appreciation Award for Poster 2013, Young Performer Award 2013, Young Pharmacy Teacher Award 2014, 2016, 2017, Best Oral Presentation Award 2014, Young Innovative Researcher Award 2014, Appreciation Award for Oral Presentation 2014, Young Talent Award 2014 (twice), 2016, Young Pharmacist Award 2015, Young Excellent Academic Award 2016 and Life Time Achievement Award 2016. Md. Rageeb Biography has been included in the renowned directory "Who's Who in the World 2016 and published in the 14 Volume, August 2016.

Cite this article: Ahmad S, Deepika S, Amol P, Kapil W, Md. Rageeb. Novel RP-HPLC Method Development and Validation of Meloxicam Suppository. Indian J of Pharmaceutical Education and Research. 2017;51(4):644-9. 